\title{
Examples of food cooperatives in Poland as a laboratory of social initiatives
}

\section{KEYWORDS}

community initiatives, community institutions, public pedagogy, constructing the common good

\begin{abstract}
Bohdan Skrzypczak, Examples of food cooperatives in Poland as a laboratory of social initiatives. Culture - Society - Education no. 2(18) 2020, Poznań 2020, pp. 69-81, Adam Mickiewicz University Press. ISSN 2300-0422. DOI 10.14746/kse.2020.18.3.2.

The paper discusses new forms of social collaboration that have been actively developing in cities for a number of years now. The text analyses the form of social interactions that the author has defined as a community institution. Applying this cognitive category to a reflection on a specific example - a food cooperative - made it possible to capture the characteristic features of a community self-organisation mechanism. Discovering the institutional aspects of the discussed phenomenon made it possible to observe that community collaboration involves an educational process of constructing the common good and consequently - a major potential of pedagogical impact and significant impact on local public policies.
\end{abstract}

Pedagogical reflection on the category of coexistence has been actively developing at least for a couple of years now. A sub-paradigm referred to as the pedagogy of coexistence gradually develops, which tries to describe and define the concepts of competition, cooperation and collaboration mainly in the area of education practice (Dymara, 2014: 35). We observe parallel eruption of diverse forms of civic

* ORCID: 0000-0001-6982-8621. 
and social collaboration in the public space and sphere ${ }^{1}$. The educational aspects of such activity constitute the research field of the concept of public pedagogy understood as a sub-paradigm/perspective of social pedagogy, which the author has been developing for a number of years (Skrzypczak, 2016a). Some of the phenomena of the new type of social coexistence is referred to as community initiatives ${ }^{2}$ (Skrzypczak, 2016b). This paper presents - using the example of food cooperatives - the community self-organisation and institutionalisation mechanism that results in an educational process of creating the common good.

\section{City - a laboratory of community initiatives}

Descriptions of new community initiatives are often focus on their spontaneity, informal nature of activities and autonomous thinking about social and civic participation. Such cooperation enables every person, even one that has no strength or individual significance, to change the rules of the game and be able to influence the surrounding reality together with others. The new community dimension of civic initiatives has its source in the social bonds transformations that took place in late 20th century, growing individualisation being their most pronounced feature. Individuals are required to lead an independent life, influence their identity and biography and autonomously determine their own norms and standards (Beck, Giddens, Lash, 2009: 29). Meanwhile, the term "community" is to a large extent the effect of the expansion of the Internet technology, which gave a new meaning to the concept of community. Because the Internet and mobile phones facilitate communication, resulting in an increased frequency of interactions with others, various communities have developed that provide an individual with support, company, information or a sense of social connectedness. This social experience is a foundation for a new "architecture of participation" that involves using the user's potential, i.e. engaging groups and communities in activities based on mutual support, communication and cooperation. By means of interactive network communication, common people can now do things that used to be available only to large and centralised organisations. Such phenomena have led to the development of the community sector, which is separate from the non-government sector, in the

\footnotetext{
1 The issue was discussed during the Polish Discussion Forum of Social Pedagogues The Pedagogy of coexistence as an inspiration to engage in the local life at the Faculty of Educational Studies at Adam Mickiewicz University and this paper was written within the framework of that Forum.

${ }^{2}$ Some examples of this include: time banks, community gardens, cooperatives, fix-it cafés, community/neighbourhood centres, community-supported agriculture or foodsharing initiatives.
} 
area of civic activity (Chimiak, Iwińska, 2014; Krenz, Mocek, Skrzypczak, 2015). Meanwhile, in the economic area, we observe the development and expansion of the sharing economy. What is common for both trends is the community collaboration mechanism. A particularly inspiring example of this phenomenon are food cooperatives that operate at the junction of social, civic and economic activity. While using modern means of network communication and social media, they strongly draw on traditions - the ideology and movement of cooperatism of the turn of the 20th century.

These days, cooperatives and other communities are actively created and developed in cities. The existence of a city is founded on simultaneous cooperation of many groups of people. Importantly, this not only serves to satisfy the file needs of residents and visitors but it also creates symbolic significance. Living in a city is associated with a certain paradox. On the one hand, it involves alienation and, on the other hand, cities are spaces strongly saturated with interpersonal contacts caused by a high population density (Kłosińska, 2010). Living in a city means living "in a crowd", but at the same time cities give more freedom, more choices and more possibilities for mobility than small rural communities. Zygmunt Bauman (2013: 15) notes in Razem czy osobno: "Physical proximity of strangers [...] is the fate of city dwellers who have to experiment, try and check various ways of life, hoping that one day, they will find a modus vivendi that will make living among strangers acceptable. This is why innovative group bond creation and community management strategies have developed in cities. Today, cities are laboratories of the future, where new forms of living together and creating the common good are discovered and invented" (Bendyk, Hausner, Kudłacz, 2015: 122).

Experimenting becomes a part of urban policy. An example of how to stimulate urban innovation in an organised way are innovation labs created in many European and Polish cities. They are organisational units (managed by local authorities or non-government organisations contracted by the city) that design, test and scale social innovation within the framework of cross-sectoral cooperation. Elżbieta Bińczyk writes: "the laboratory is specific space, where possible social systems/ ideas are intentionally created, the focus being not on theoretical concepts, but instead on practical success, which means successful operation in a specific community and certain repeatability of results" (2013: 64). One of such initiatives was the Warsaw Laboratory of Local Innovation, which operated from 2016 to 2018 under the Warsaw Locally programme ${ }^{3}$. The Laboratory focused on finding mech-

\footnotetext{
${ }^{3}$ It was conducted by the Centre for Promoting Local Activity (Centrum Wspierania Aktywności Lokalnej CAL) in Warsaw and financed from the budged of the Warsaw local government. The research work was managed by the author of the paper - Bohdan Skrzypczak.
} 
anisms to create social bonds and cooperation among the residents of Warsaw. Research and environmental debates were maintained in the trend that the author refers to as public pedagogy and they concerned pedagogical contexts of the impact of bottom-up self-organisation initiatives of residents and educational forms of their promotion (or lack of it) in urban public policies. Among the 16 case studies of community initiatives developed in the laboratory, there was one concerning food cooperatives that presented the educational and community mechanisms of cooperation and coexistence in urban space in the most comprehensive manner (Skrzypczak, Urbańska, 2016). The study, some elements of which are discussed in this paper, presents the working mechanisms of a cooperative from three cognitive perspectives: 1) a self-organising and multifunctional community; 2) creation of a new type of community institution; and 3) triggering the educational process of building the common good.

\section{Multifunctional consumerist and educational community}

"Cooperative is an informal food company. It is the initiative of conscious consumers and it is created by a community that wants to have access to healthy food at fair prices. We build a network of cooperation between manufacturers and consumers in order to satisfy the needs of the parties, rather than to gain profit. Members of the cooperative are interested in putting into life the idea of cooperation. This enables us to buy products much cheaper, usually directly from manufacturers" - declare members of the Warsaw cooperative on their website (Bilewicz, 2015: 1). However, food cooperative is not only about buying healthy food every week. Individuals engaged in the cooperative also note that it serves economic and educational goals. The cooperative enables its members to make new acquaintances, exchange opinions and implement new joint projects addressed to the local community. "This is not about an efficient anonymous organisation that provides cheap organic vegetables. A cooperative is about people who know and like each other and want to do something together" (Podkańska, 2013: 56). For some members of a cooperative, its social dimension is even more important than the consumer dimension. Cooperatives pursue two main goals:

- to sell food purchased directly from manufacturers at lower prices;

- to create a democratic community of mutual assistance (e.g. through a group fund consisting of $10 \%$ of the value of each purchase allocated to the common goals of the cooperative and to its members in need). 
In Warsaw, there exist ca. 10 groups that identify themselves as cooperatives. Most of them are informal groups that undergo fast transformations: some suspend their activity while others are established, new members come and go and some cooperatives move on to become formal organisations. It is estimated that one cooperative consists of 50 members on average, although some could temporarily have more than 500 members $^{4}$. Despite differences, they have certain features in common, such as the community/social dimension that will be discussed in more detail here.

Members of a cooperative appreciate in particular its community and social dimension. They organise meetings, workshops, shared meals, open picnics in parks, discussion or film shows. Research respondents say, for example, that: "Of course, food matters, but there is more to it than that; this is not only about food, because I can go to the market and buy myself some food, and it would probably be faster this way, but what is important is the group that is established. And it is also important that there is a certain community" (Podkańska, 2013: 57). Another respondent described the cooperative in the following way: "It is a small society, because in fact it is a community. Introducing a code of uniform principles and limiting the number of members of the Cooperative, made it possible to restore the original idea of community and cooperation. [...] A few months after the changes had been introduced, the Grochowska Cooperative reached the optimal size of ca. a hundred members that ensures a balance between the bargaining and purchasing power and the ability to maintain contacts and bonds with the other members" (Skrzypczak, Urbańska, 2016: 45).

The cooperative community is united and engaged in a number of functions. First of all, a cooperative is an instrument to satisfy consumer needs. For many members, its educational function is also important. Engagement in a cooperative makes it possible to develop teamwork skills and to learn how to make joint decisions and solve conflicts. In a way, this makes a cooperative a school of social competencies. Thirdly, it is a training ground to create community and neighbourhood bonds and to develop social identity. Currently, whether we like it or not, consumption to a large extent determines our identity. Accordingly, certain consumer choices, such as buying organic seasonal food at not very high prices, are an important element of designing one's identity for cooperative members. "For me, membership in a cooperative and the specific products we buy is a tool to define myself" (Podkańska, 2013: 54). Fourthly, every cooperative stimulates innovation.

\footnotetext{
${ }^{4}$ By way of comparison, in late 1930s, the largest cooperative union in Poland, called "Społem", consisted of ca. 600000 members.
} 
Thanks to the engagement and creativity of their members, many new initiatives, not linked directly with purchases, develop within cooperatives, for example: urban garden designs, a post-growth discussion group, community goods and services exchange system or Community-Supported Agriculture.

Almost all cooperatives struggle, to a greater or lesser extent, with insufficient engagement of their members. Usually, a couple of the most dedicated activists do most of the work. Some of them get burnt out and leave the cooperative. "There was a major problem connected with participation and the fact that I accepted to many duties, because there were not enough people to do the job. At one point, I just overheated and could not continue doing all the things I had to do, and had to suspend my activity for one month" (Bilewicz, 2015: 4).

Chaotic operation of cooperatives is a problem especially for those who join them mainly in order to have access to good quality and/or cheaper food. Those for whom cooperatives are a "natural environment", accept such problems more or less easily. An organisation that performs the function of a social group and whose value consists in the mere fact of existence does not need to be very efficient and effective - what is important is that it serves as a place to socialise and implement important ideas.

\section{Food cooperative as a community institution}

The author believes that interesting cognitive conclusions may be made by analysing food cooperatives through the cognitive perspective of new institutionalism. We create institutions because they help reduce the costs of social transactions and the uncertainty associated with such transactions. By shifting responsibility to an institutional level, individuals pay lower transaction costs than they would if they entered into a transaction without an intermediary. Institutions guarantee safety, regularity and low interaction costs for individuals. "They may also develop and impose their own rules on others. Individuals who establish interactions in a specific situation, governed by certain rules, associated with a given environment, may in time accept the norms of behaviour towards others and their activities. As they learn about the consequences of their own behaviour as well as that of others in a given situation, participants of said interactions may identify norms and strategies of action, which leads to better or worse consequences for them and for the environment that those actions concern" (Ostrom, 2012: 88).

The rules developed and applied in such institutions serve to integrate and trigger routine actions, procedures, roles, strategies, organisational forms and 
a group or community culture. From such cognitive perspective, informal community initiatives, which strongly criticise institutions, in the common sense of the term (i.e. as organisations), form a new kind of institutions defined as community institutions. They serve as an intermediary between an individual focused on achieving maximum benefits for themselves on one hand and a common interest on the other hand and a link between the past, the present and the future, this way reducing uncertainty in social life. According to this interpretation, institutions are not so much people as regularities (customs and rules) manifested in repetitive human interactions (North, 1986: 231). Cooperatives and other community initiatives are mostly non-hierarchical and functions such as delivery of goods, weighing, collecting money or cleaning are performed on a shift basis. In an attempt to streamline their operation, some of them have introduced the function of coordinators, whose term of service lasts for a few months. They are based on direct cooperation with farmers, especially small farms that grow organic products.

A cooperative is an informal organisation with a flat management structure, where decisions are made in accordance with the principle of consensus. Supplies are organised on a shift basis; the members are divided into groups that take turns organising subsequent supplies of products. It is not mandatory to buy products or to engage in the supply of products, which leads to a growing problem of "fare dodgers" (Podkańska, 2013: 56). It is important to constantly encourage members to buy products and to actively engage in their supply. One of the main goals of a cooperative is to develop the best model for the organisation of food production and distribution, which will provide members of a group with access to healthy and cheap products directly from farmers. Members of a cooperative wish to regain control over consumer choices and for many of them, contacts with food producers or direct involvement in food supplies constitutes a more important value than the fact that specific products have organic food certificates. They often stress that their goal is to operate outside the commercial market, because they want to be active on the local market and promote local farmers. They declare that their goal is not to revolutionise, but rather to develop an alternative food production and distribution model and to test it on a small scale (Skrzypczak, Urbańska, 2016: 28).

A cooperative is also an attempt to reconstruct the culture of collaboration in projects that are aimed not at generating profit but instead at achieving common goals. An important mechanism of the institutional development of cooperatives is cooperation with other public or non-government institutions. "Access to space in the Social Centre Paca 40 (an organisation that provides free-of-charge space for pickup of products) for the purpose of weekly pickup of products increases the 
operating possibilities of the Cooperative. It has enabled the cooperative to develop very dynamically. The number of suppliers has grown, and sometimes there are products from more than twenty suppliers available for pickup; the selection of dairy, poultry and meat products has increased significantly and storage space with two fridges donated by members of the cooperative gives much better opportunities" (Skrzypczak, Urbańska, 2016: 38).

Food cooperatives, even though they try to achieve a certain level of predictability and regularity of socio-economic transactions that an institution is supposed to ensure at the same time believe that too many regulations are ineffective and undesirable. George Ritzer (1997) called this phenomenon the irrationality of rationality. Since the Polish legal system does not provide for the existence of cooperatives, they are not defined as a legal concept. Thus, food cooperatives in Poland do not have a legal personality and instead, they operate on the basis of their internal regulations that are adopted in a participatory manner and clearly and precisely define the duties of their members and oblige all to be actively engaged. Every member must buy something at least once every two months and spend at least three hours a month working for the group. Such work may involve, for example, cleaning the storage space after pickup of products, helping new members of the organisation with their first assignments, checking memberships fee accounts, acquiring new supplier or coordinating procurement. "Another option is to do some work for the Centre Paca 40 or organise workshops, speeches or events. Time accounting is arbitrary; what is important is that everyone feels to be accountable for the community - all work done for the Cooperative is reported in an engagement table" (Skrzypczak, Urbańska, 2016: 37). The regulations and other documents concerning the operation of the Cooperative are available online. The Cooperative has its Facebook group. In this closed group, detailed event information is published, current issues are discussed and all kinds of announcements are made. Descriptions of events are linked to order tables that are available in a cloud and developed based on a uniform format. "Simple and generally available tools and social website as a functioning platform for the Cooperative are extremely useful" (Skrzypczak, Urbańska, 2016: 41).

Cooperatives are an interesting combination of the "economic man" (homo economicus) and the "citizen-man" (homo politicus) who is eager to cooperate and renegotiate the rules of social games and interested in fostering collective bonds. With such approach, the focus is on cooperation as a more beneficial strategy than pushing forward an individual calculation. This type of economic cooperation proves to be a school of democracy, because it teaches all the stakeholders in a practical and engaging manner how to build social order through bottom-up 
initiatives. This is associated with a pedagogical understanding of an institution, according to which an institution not only exists in the real world but it may also be an imagined and symbolic construct. The mutual associations and tensions in the social space between what is real (we are not pleased with it, we criticise the existing institutions) and what is imagined and symbolic (the way we would like things to be) may be an important element that triggers change.

The examined cases reveal two-dimensional perception of an institution. Firstly, it is a rule (pattern) and secondly, an entity that may relate to other entities (the type of an organisation). In this approach, it is important to cognitively separate institutions from organisations, even though they both serve to put human activity into order (Granosik, 2013: 67). In the case of cooperatives, two separate paths of social practice are very clearly visible: the first is associated with a reflection on the sense of "being together" in an enterprise and the second improves the organisational and economic dimensions of the structure.

It should also be noted that institutions have a very strong collective mechanism in them and their collective activities appear as an alternative to the activity of selfish individuals. A social (and community) institution is more than the sum of activities undertaken by respective individuals. A reflection on the (re)construction of civic institutions that stems from this basis assumes that "the world [...] is not a private world of a specific individual but an intersubjective world that we all share and that is for us a highly practical rather than theoretical object of interest. [...] constitutes both the scene and object of our activities and interactions" (Schütz, 2008: 18). In this area, cooperatives constitute an interesting innovation that combines contradictory (at least apparently) approaches: it contains a strong community element, while at the same being exclusive and strongly emphasising the individualism.

Cooperatives create a management model that enables cooperation between individuals who can see the benefits of joint activities, this way generating an economically effective enterprise. Users - so-called pro-sumers, i.e. persons who at the same time produce and consume, use shared resources, which means that the use of resources depends on the decision of a group - if you are a member of a group, you have the right to use its resources. Shared use of resources is a major economic and social challenge. Shared work and use may lead to a dilemma that will force respective members of a group to choose between their own short-term interests and long-term benefits for the community. The "Commoners" create institutional rules than enable interactions within a groups and make it possible to solve the abovementioned dilemmas. The effect is a new institution of collective action a community institution. Its form and functioning significantly differ from the 
market or local or state government model of management. The key mechanism that bonds this form of cooperation is the principle of reciprocity and equality in decision-making processes. In order to enforce the principle of reciprocity, it is necessary to include people in decision-making processes and the management of the common good. This new institutional system offers sufficient usefulness to individual users while at the same time preventive excessive consumption of common resources. When analysing the social and institutional mechanisms of cooperatives, it is possible to identify certain common rules and methods of communication and operation that comprise the organisational culture that the author has defined as the community institution.

Table 1 . The features of the community institution

\begin{tabular}{|c|c|}
\hline Rules of cooperation & Methods of operation \\
\hline $\begin{array}{l}\text { - based on the principle of reciprocity and ex- } \\
\text { change of knowledge/experience between } \\
\text { members } \\
\text { - mutual motivation and support with elements } \\
\text { of control } \\
\text { - democratic organisational structure }\end{array}$ & $\begin{array}{l}\text { - no formal limitations or bureaucracy associated } \\
\text { with project implementation } \\
\text { - freedom of action, freedom of decisions, civic } \\
\text { activity in its "pure form" } \\
\text { - innovation understood as implementation of } \\
\text { new ideas in the micro scale which usually con- } \\
\text { cern a narrow field of the reality (collectivity) } \\
\text { - focus on action rather than on methods and } \\
\text { theories }\end{array}$ \\
\hline Culture of action & Principles and forms of communication \\
\hline $\begin{array}{l}\text { - social and civic activity understood as a dimen- } \\
\text { sion of identity and lifestyle } \\
\text { - social initiatives stem from autonomous (spon- } \\
\text { taneous or strategic) decisions of active mem- } \\
\text { bers, whose activities are oriented at changing } \\
\text { the "here and now" } \\
\text { - resistance and critique of the dominant lifestyle } \\
\text { and the non-government sector }\end{array}$ & $\begin{array}{l}\text { - active communication and contacts through } \\
\text { electronic media (social media) } \\
\text { - network-based cooperation and relationships } \\
\text { - non-hierarchical communication }\end{array}$ \\
\hline
\end{tabular}

Source: own elaboration.

\section{Creating the institution of the common good as an educational challenge}

Contemporary pedagogical deliberations on public affairs frequently mention the common good, which means, "first of all, a social order that is liberating and is based on cooperation, or the creation of institutions specifically designed in order to liberate free people; secondly - specific social achievements; thirdly - a point 
of reference" (Novak, 1998: 125). This is supposed to be a social order that is tailored to free people, and as such cannot be imposed by the authorities. According to the dominant public discourse in Europe, the market is the best social device to achieve common purposes. It was assumed that the weaknesses of the market may be balanced by relevant public institutions. However, such institutions quickly turn into bureaucratic structures that are unable of fulfilling the hopes of a community. Due to lack of solutions in the mainstream public policy, alternative ideas have developed.

Community institutions, such as the food cooperative presented in this paper, may hopefully meet most of the requirements associated with the creation of the common good. First of all, they combine economic and social as well as collective and individual aspects. Secondly, they are created when a certain community decides to collectively manage a certain resource, taking into consideration access to and the advantages of that resource and the principle of maintaining the economic balance. Thirdly, they use the latest communication technologies, while at the same time drawing on traditions. The new - community-based interpretation of the common good and the new understanding of cooperation is accompanied by activation of a social movement that can be described, after Ivan Illich, as vernacular (Illich, 1981). This type of activity - movement concerns informal cultural space, where people make independent moral choices and have clearly delimited autonomy. This is a space that is shared between a community, where shared values and goals are more important than the interest of the State and corporations. Peter Linebaugh (2008) writes that there is no common good without "communing", which means the decisions of a given community. The road to such understanding of the common good requires practical thinking, noticing the creative potential of social relationships and abandoning abstract, universal, procedural or legal quests. What matters is the relationship "here and now", rather than abstract planning of the common good sometime in the future. The common good understood in the community way works when people learn and experience management in a specific and unique way resulting from the specific resources of a community. The personal and collective relationship between people and their resources is important (Boiler, 2014: 15). In this approach, the common good is a self-education idea implemented by applying the practice of a learning community and developing and implementing a set of community measures, i.e. the values and norms that are necessary to manage resources. The "educational and community mechanism" understood in this way is contained in the following formula: "community + integration/development of the community by creation of internal networks and external relations + institutionalising the community through negotiations/introduction of 
a set of procedures and social values = triggering internal and external resources". When all the factors exist together, an interdependent and holistic common good is created (Boiler, 2014: 16). Many things suggest that food cooperatives and many other community initiatives/institutions have found their own path to introduce the above educational mechanism into the social practice, which undoubtedly fills with hope pedagogues who have been searching for an effective pedagogy of the common good for a long time.

\section{Bibliography}

Bauman Z. (2003), Razem czy osobno, Kraków.

Beck U., Giddens A., Lash S. (2009), Modernizacja refleksyjna. Polityka, tradycja i estetyka w porzadku społecznym nowoczesności, Warszawa.

Bendyk E., Hausner J., Kudłacz M. (2016), Miasto-idea - nowe podejście do rozwoju miast, Kraków.

Bilewicz A. (2015), Samoograniczająca się zmiana? Kooperatywy spożywcze w Polsce, „Nowy Obywatel", http://nowyobywatel.pl/2015/05/06/samoograniczajaca-sie-zmiana-kooperatywy-spozywcze-w-polsce/ [access: 20.04.2019].

Bińczyk E. (2013), (Post)konstruktywizm na temat technonauki, „Avant”, vol. 4, no. 1.

Bollier D. (2014), The Commons. Dobro wspólne dla każdego, Zielonka.

Chimiak G., Iwińska K. (eds.) (2014), Krajobraz społecznościowy, Warszawa.

Dymara B. (2014), Źródła, cechy i perspektywy pedagogiki współbycia, in: Dziecko w świecie innowacyjnej edukacji, współdziałania $i$ wartości, vol. 1, eds. U. Szuścik, O. Oelszlaeger-Kosturek, Katowice.

Granosik M. (2013), Praca socjalna - analiza instytucjonalna z perspektywy konwersacyjnej, Łódź.

Illich I. (1981), Shadow Work, Boston.

Kłosińska M. (2010), Granice miejskości, „Antropos”, 14/15, file:///Users/Bohdan/Documents/ Moje\%20dokumenty/WARSZAWA/warszwskie\%20laboratorium/miejskość/miejskość.webarchive [access: 15.04.2017].

Linebaugh P. (2008), The Magna Carta Manifesto: Liberties and Commons for All, Berkeley.

Mocek S., Skrzypczak B. (eds.) (2015), Efekt motyla. Scenariusze rozwoju sektora społecznościowego $w$ Polsce, Warszawa.

North D.C. (1986), The New Institutional Economics, „Journal of Institutional and Theoretical Economics", vol. 142.

Novak M. (1998), Wolne osoby i dobro wspólne, Kraków.

Ostrom E. (2012), Instytucje i środowisko, „Zarządzanie Publiczne”, no. 2 (20).

Potkańska D. (2014), Zmierzch epoki tradycyjnego konsumenta, czyli jak wspólne zakupy ekologicznej żywności kształtują tożsamość społeczna młodych Polaków. Odradzający się ruch żywieniowy kooperatyw spożywczych $w$ Polsce - przykład Warszawy, http://docplayer.pl/13473092-Dominika-potkanska-zmierzch-epoki-tradycyjnego-konsumenta-czyli-jak-wspolne-zakupy-ekologicznej-zywnosci-ksztaltuja-tozsamosc-spoleczna-mlodych.html [access: 02.03.2018].

Ritzer G. (1997), Makdonaldyzacja społeczeństwa, Warszawa.

Schütz A. (2008), O wielości światów. Szkice z socjologii fenomenologicznej, Kraków. 
Skrzypczak B. (2016a), Współczynnik społecznościowy - edukacyjne (re)konstruowanie instytucji społecznościowych w perspektywie pedagogiki społecznej, Toruń.

Skrzypczak B. (2016b), Pomiędzy społecznym a publicznym - nowa przestrzeń edukacji i refleksji, „Pedagogika Społeczna”, no. 3 (61).

Skrzypczak B., Urbańska A. (2016), Kooperatywa spożywcza jako instytucja społecznościowa. Studium przypadku, Warszawa. 
